УДК 338.4:69.003

DOI https://doi.org/10.32851/2708-0366/2021.7.6

Серьогіна Н.В.

кандидат економічних наук, доцент кафредри економіки та підприємництва, Одеська державна академія будівництва та архітектури ORCID: https://orcid.org/0000-0001-8612-6429

Кобилянська О.І. студентка,

Одеська державна академія будівництва та архітектури

Serohina Nataliia, Kobylianska Olha

Odessa State Academy of Civil Engineering and Architecture

\title{
ТЕНДЕНЦІЇ РОЗВИТКУ РИНКУ ЖИТЛОВОГО БУДІВНИЦТВА
}

\section{TRENDS IN THE DEVELOPMENT OF THE HOUSING CONSTRUCTION MARKET}

\begin{abstract}
Статтю присвячено дослідженню проблем на ринку житлової нерухомості, який є соціально значушим елементом сектору господарювання, та виявленню сучасних тенденцій, які відбуваються у житловому будівництві України. Зазначено, щзо вирішення проблем у житловому будівниитві залежить від упровадження заходів щзодо підвищення ефективності діяльності будівельних підприємств та платоспроможності населення. Для визначення напрямів підвищення ефективності діяльності будівельних організацій проаналізовано загальні площуі житлових будівель, прийнятих в експлуатацію, проведено порівняння результатів із плановими показниками, у тому числі за видами будівель. Зроблено висновки щуодо необхідності переорієнтації діяльності частки невеликих будівельних організацій на будівництво приватних будинків, щзо забезпечить їм стабільний та надійний прибуток через указані причини.
\end{abstract}

Ключові слова: житлове будівнищтво, площчі житлових будівель, фінансовий добробут, доходи населення, кредитування.

Статья посвящена исследованию проблем на рынке жилой недвижимости, который является сочиально значимым элементом сектора хозяйствования, и выявлению современных тенденций, которье происходят в жилищном строительстве Украиньл. Указано, что решение проблем в жилищном строительстве зависит от внедрения мероприятий по повышению эффективности деятельности строчтельных предприятий и платёжеспособности населения. Для определения направлений повышения эффективности деятельности строительных организаций проанализированы общчие площзади жильх зданий, принятых в эксплуатацию, проведено сравнение результатов с плановыми показателями, в том числе по видам зданий. Сделаны выводы о необходимости переориентации деятельности доли небольших строчтельных организаций на строительство частных домов, что обеспечит им стабильный и надёжный доход по указанным причинам.

Ключевые слова: жилищное строительство, площуади жильх зданий, финансовое благополучие, доходы населения, кредитование.

The purpose of this article is to identify current trends in housing construction in Ukraine, analysis of its condition and identify factors influencing the dynamics of its development. The methodological and informational basis of the work is scientific works, materials of periodicals and official sites. The research used methods of analysis, synthesis, comparison, grouping and generalization. The article is devoted to the study of problems in the residential real estate market, which is a socially significant element of the economic sector and to identify current trends in housing construction in Ukraine. The relevance of the study is due to the constant change of factors influencing the construction of real estate, monitoring of which is necessary for effective planning of construction companies. Due to such factors, an idea of promising areas of housing development, quality of housing, its main functional purpose and level of comfort is formed. The article states that the solution of problems in housing construction depends on the 
implementation of measures to improve the efficiency of construction companies and the solvency of the population. To determine areas for improving the efficiency of construction companies, analyzed the total area of residential buildings put into operation, compared the results with the planned indicators, including the types of buildings. The discrepancy between the planned indicators of housing construction volumes and the actual results was revealed. The dynamics of change of indicators is analyzed. The obtained results prove the need for more careful observance of the design terms of construction with the subsequent revision and change of shares of types of buildings at planning. It is also noted that the financing of housing construction also has certain problems, as does the purchase of housing due to the low financial well-being of a significant part of the population. As a result, the construction of private homes is in growing demand due to the fact that the buyer has a greater choice of their own desires and solutions, which can meet a very large price range. Conclusions are made on the need to reorient the activities of small construction companies to the construction of private homes, which will provide them with a stable and reliable income for these reasons.

Key words: housing construction, areas of residential buildings, financial well-being, income of the population, lending.

Постановка проблеми. Сьогодні галузь будівництва має надзвичайно велике значення для динамічного розвитку України і розв'язання великого комплексу соціальних та економічних проблем [1]. Серед проблем господарського реформування можна виділити наявність певних проблем на ринку житлової нерухомості, який є соціально значущим елементом сектору господарювання. Розвиток ринку житлової нерухомості суттєво впливає на економічний розвиток регіонів України, а проблеми житлового будівництва потребують постійного дослідження, що зумовлено динамікою змін чинників впливу на цей сектор.

Вирішення житлової проблеми, особливо для такої категорії населення, як молодь, $€$ пріоритетом у соціально-економічній політиці країни, оскільки нині відбуваються негативні демографічні процеси (чисельність населення зменшується, питома вага осіб похилого віку зростає, а питома вага дітей у загальній структурі населення зменшується тощо). Тому важливим напрямом щодо підвищення рівня народжуваності, шлюбності, зменшення кількості розлучень у країни є вирішення житлової проблеми [1].

Аналіз останніх досліджень і публікацій. Проблеми розвитку будівельної галузі та будівельних підприємств, взаємозв'язок будівництва та економіки країни, а також механізми функціонування ринків нерухомості розглядали у своїх роботах В. Биба, Р. Тяна, М. Іванов, І. Грищенко, Л. Григор'єва, А. Асаула, В. Вороніна, І. Молчанов, T. Одаренко, I. Заюков [1], В. Заяць [2] та ін. Однак постійні зміни чинників, що здійснюють вплив на будівництво нерухомості, доводять необхідність регулярного дослідження стану житлового будівництва та визначення перспектив його розвитку.

Формулювання цілей статті. Метою статті є виявлення сучасних тенденцій, які відбуваються у житловому будівництві України, аналіз стану житлового будівництва в країні та виявлення чинників впливу на динаміку його розвитку.

Виклад основного матеріалу. Під впливом суспільних еволюційних змін поступово трансформуються уявлення про перспективні напрями розвитку житлового будівництва, якість житла, його основне функціональне призначення і рівень комфортності. Першопричиною цих змін $є$ розвиток суспільних відносин, притаманних різним соціально-економічним системам, а також найбільш впливових на формування житлових умов населення секторів економіки. Житлове будівництво стимулює підвищення якості життя населення, впливає на темпи інфляції та безробіття, а головне - залучає довгострокові інвестиції у поліпшення житлових умов населення. За будь-яких умов житло є одним з основних матеріальних благ, необхідних для успішної організації життєдіяльності людини та реалізації ії життєвих цілей. Потреба в житлі є базовою, вона виникає з народження людини і зберігає вагоме значення протягом усього життя, а його основні характеристики є індика- 
торами якості життя. Житлові умови населення залежать від тенденцій розвитку житлового будівництва, його орієнтації на потреби споживачів та збалансованості розвитку ринку житлової нерухомості [2]. Відповідно скорочення та зростання обсягів житлового будівництва залежать від низки причин: зміни рівня витрат на будівництво, цін на житло, процентних ставок за банківськими кредитами та інших, що відображалися на коливанні попиту та пропозиції на житло.

Вирішення зазначених проблем залежить від упровадження відповідних заходів у двох напрямах: підвищення ефективності діяльності будівельних підприємств та платоспроможності населення. Слід зазначити, що підвищення платоспроможності населення як єдиного засобу стимулювання житлового будівництва не є ефективним. Підвищення ефективності діяльності будівельних підприємств необхідне для формування відповідного асортименту та стабілізації цін на ринку житла.

Для визначення напрямів підвищення ефективності діяльності підприємств, які займаються житловим будівництвом, слід ретельно вивчити існуючу ситуацію у житловому секторі будівельної галузі. Одним із найбільш наочних показників розвитку житлового будівництва $є$ загальна площа житлових будівель, прийнятих в експлуатацію. Оскільки це натуральний показник, динаміка його зміни $є$ більш інформативною на відміну від вартісних показників, які залежать від впливу більшої кількості чинників, у тому числі ринкових. Розглянемо динаміку зміни загальних площ житлових будівель, прийнятих в експлуатацію за останні три роки, показники яких наведено в табл. 1, побудованої на основі даних Державної служби статистики України [3].

Таблиця 1

Загальна площа житлових будівель, прийнятих в експлуатацію

\begin{tabular}{|c|c|c|c|c|c|c|c|}
\hline & \multicolumn{7}{|c|}{ Періоди } \\
\hline & \multirow{2}{*}{$\begin{array}{c}2018 \\
\text { Кв. M }\end{array}$} & \multicolumn{2}{|c|}{2019} & \multicolumn{2}{|c|}{2020} & \multicolumn{2}{|c|}{ I квартал 2021} \\
\hline & & KB. M & $\begin{array}{c}\text { у \% до } \\
\text { поперед- } \\
\text { нього } \\
\text { року } \\
\end{array}$ & KB. M & $\begin{array}{c}\text { у \% до } \\
\text { поперед- } \\
\text { нього } \\
\text { року }\end{array}$ & КВ. M & $\begin{array}{c}\text { у \% до } \\
\text { поперд- } \\
\text { нього } \\
\text { року } \\
\end{array}$ \\
\hline Усього, у т. ч.: & 8689356 & 11029327 & 126,93 & 5749921 & 52,13 & 2306431 & 40,11 \\
\hline $\begin{array}{l}\text { будинки } \\
\text { одноквартирні }\end{array}$ & 4247660 & 5847163 & 137,66 & 3092248 & 52,88 & 991678 & 32,07 \\
\hline $\begin{array}{l}\text { будинки } 3 \\
\text { 2-ма та більше } \\
\text { квартирами }\end{array}$ & 4434586 & 5176389 & 116,73 & 2651954 & 51,23 & 1305061 & 49,21 \\
\hline гуртожитки & 7110 & 5775 & 81,22 & 5719 & 99,03 & 9692 & 169,47 \\
\hline
\end{tabular}

Джерело: сформовано авторами на основі [3]

Аналізуючи дані, наведені в табл. 1, можна спостерігати в 2020 р. значне скорочення загальних площ житлових будівель, прийнятих в експлуатацію, - майже $48 \%$. Однак у попередньому 2019 р. було суттєве зростання показників, особливо по одноквартирних будинках, - на 37,66\%, тільки здача в експлуатацію площ гуртожитків скоротилася майже на 19\%. Результати першого кварталу 2021 р. показали тенденцію до значного зростання, оскільки лише за три місяці було здано 40\% загальної площі будівель порівняно з показником за весь 2020 р. Особливо виділяється кількість зданих в експлуатацію площ гуртожитків - вони більше торішніх на $69,5 \%$ за такий короткий термін. Такі зміни дають змогу припустити, що в 2021 р. може відбутися значне зростання у житловому будівництві, але, як уже було зазначено вище, вплив інших чинників може погіршити таку динаміку. 
Для більш наявного відображення ситуації необхідно розглянути та порівняти заплановані та отримані результати за площами житлових будівель. Представимо загальний результат за всіма видами житлових будівель на рис. 1 у вигляді графіка, на якому наведено заплановані та здані в експлуатацію площі. Графік побудовано згідно 3 даними Державної служби статистики України [4].

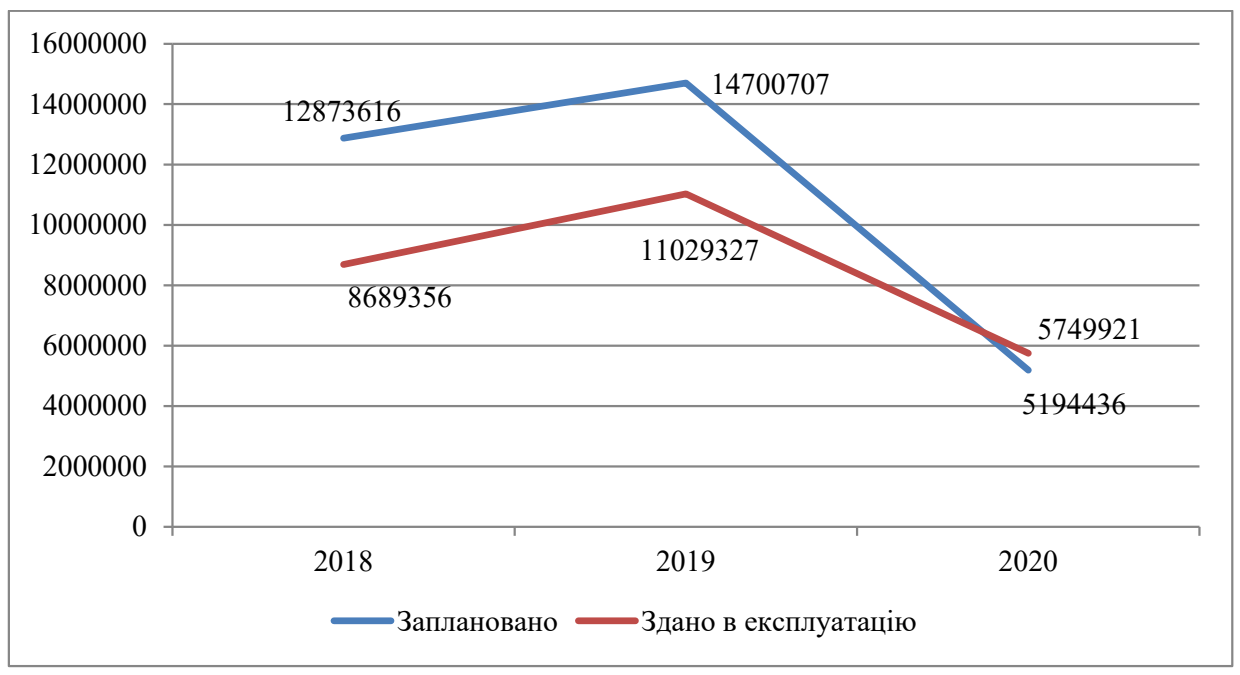

Рис. 1. Порівняння запланованих

та зданих в експлуатацію площ, житлових будівель, кв. м

Джерело: сформовано авторами на основі [4]

Отримані результати демонструють затримки в попередні роки по здачі в експлуатацію запланованих площ, що призвело до перевищення у 2020 р. зданих площ житла над запланованими на початок будівництва. Така тенденція може свідчити про недотримання термінів будівництва відповідно до проєктних рішень, що є досить поширеною практикою в Україні, а також про недостатність фінансування, яка сповільнює темпи будівництва об'єктів.

Але також це може свідчити про переваження частки крупних проєктів із великими термінами зведення будівель у загальній кількості житлових будівництв. Для підтвердження такого припущення треба більш детально проаналізувати планові показники та їх відхилення від фактичних показників за окремими видами житлових будівель. Дані для аналізу наведено в табл. 2, яка побудована згідно з даними Державної служби статистики України [4].

Отримані результати показали значне відхилення фактичних показників від запланованих на початок будівництва. На протязі всього проаналізованого періоду площі одноквартирних будинків планувалися нижчими від фактично отриманого результату у 10 разів: таке відхилення залежало, перш за все, від зміни попиту на такий вид будівель. Однак подібна тенденція протрималася протягом трьох років, що доводить необхідність перегляду частки приватних будинків у запланованих обсягах житлового будівництва. Окрім того, це надає можливість невеликим будівельним організаціям змінити профіль діяльності на будівництво у приватному секторі, що може поліпшити фінансові результати їхньої діяльності.

Показники по багатоквартирних будинках показали зворотну тенденцію: фактичне виконання суттєво менше запланованих обсягів - майже у три рази. Причин такого 
відхилення може буде багато, до основних із них відносяться недостатнє фінансування будівництва, скорочення попиту на квартири, недосконалість організації та планування будівництва і перенасиченість даного сегменту ринку житла. Слід зазначити, що в 2020 р. різниця між запланованими та фактичними показниками скоротилася до $184,39 \%$, що можна пояснити завершенням довгострокових будівництв, але цього недостатньо для того, щоб уважати планові показники об'єктивними.

Таблиця 2

Загальна площа житлових будівель на початок будівництва за видами

\begin{tabular}{|l|c|c|c|c|c|c|}
\hline \multirow{2}{*}{$\begin{array}{c}\text { Житлові } \\
\text { будівлі } \\
\text { за видами }\end{array}$} & \multicolumn{2}{|c|}{$\mathbf{2 0 1 8}$} & \multicolumn{2}{|c|}{$\mathbf{2 0 1 9}$} & \multicolumn{2}{|c|}{$\mathbf{2 0 2 0}$} \\
\cline { 2 - 7 } & кв. м & $\begin{array}{c}\text { у \% до } \\
\text { фактичних } \\
\text { показників }\end{array}$ & кв. м & $\begin{array}{c}\text { у \% до } \\
\text { фактичних } \\
\text { показників }\end{array}$ & $\begin{array}{c}\text { у \% до } \\
\text { кактичних } \\
\text { показників }\end{array}$ \\
\hline $\begin{array}{l}\text { Будинки } \\
\text { одноквартирні }\end{array}$ & 417597 & 9,83 & 290183 & 4,96 & 300428 & 9,72 \\
\hline $\begin{array}{l}\text { Будинки з } \\
\text { 2-ма та більше } \\
\text { квартирами }\end{array}$ & 12442252 & 280,57 & 14362898 & 277,47 & 4889963 & 184,39 \\
\hline Гуртожитки & 13767 & 193,63 & 47626 & 824,69 & 4045 & 70,73 \\
\hline
\end{tabular}

Джерело: сформовано авторами на основі [4]

Щодо будівництва гуртожитків, то можна зробити висновок, що 2020 р. також відрізняє деяке порушення загальної тенденції. У 2018-2019 pр. заплановані показники площ гуртожитків суттєво не відповідали фактичному виконанню через необгрунтовано завищенні плани, а саме перевищення становило 93,63\% та 724,69\%, але в 2020 р. здані в експлуатацію площі гуртожитків перевищили заплановані показники на $29,27 \%$. Це також може пояснюватися закінченням будівництв, розпочатих у попередні роки.

Отримані результати доводять необхідність більш ретельного дотримання проєктних термінів будівництва 3 подальшим переглядом та зміною часток видів будівель під час планування.

Однією з причин коливання попиту на різні форми житлового будівництва є зниження рівня фінансового добробуту населення: значна частка населення не може дозволити себе купівлю квартир через рівень цін.

Специфіка ринку житла в Україні як механізму забезпечення житлових потреб населення полягає у тому, що він зорієнтований на людей із високим рівнем доходів. У період ринку житлове будівництво все більше орієнтувалося лише на кошти приватних інвесторів. Це призвело до того, що зі знаряддя реалізації державної соціальної політики будівництво житла перетворилося на високоприбутковий бізнес, який у процесі функціонування вирішує два різнорідних завдання - задоволення економічних інтересів девелоперських чи приватних будівельних компаній та задоволення житлових потреб платоспроможної частини українського суспільства [5]. Ситуація дещо погіршилася у 2020 р. у зв'язку з пандемією, яка відобразилася на зайнятості населення, рівні заробітних плат та можливості виплачувати кредити.

Для збільшення обсягів житлового будівництва необхідним є збільшення обсягів інвестицій. Але інвестування у будь-які об'єкти будівництва, як відомо, характеризується досить високим ступенем ризику через значні капіталовкладення та довготривалість виробничих процесів. Існує багато форм та джерел інвестування у житлове будівництво, але можна виділити основні напрями: 
- фінансування за рахунок власних коштів будівельних компаній;

- фінансування за напрямами комерційного кредитування будівельних організацій;

- потечне кредитування приватних забудовників та покупців готового житла [6].

Нестабільність зовнішнього оточення призвела до скорочення пропозицій та попиту на іпотечне кредитування. Банківська сфера не працює з достатньою ефективністю на цьому ринку. Подальша перспектива розвитку іпотеки значно залежить від стабільності політико-економічної ситуації в країні, загального зміцнення економіки, змін курсу національної валюти, удосконалення фінансово-кредитної системи. Розвиток іпотечного кредитування позитивно вплине на формування ринку нерухомості [7].

Досить поширеною є практика купівлі житла на стадії зведення будинку, що дещо активує фінансування будівництва. Але таку можливість має дуже незначна частка населення, хоча подібна форма є більш вигідною порівняно з купівлею квартир після здачі їх в експлуатацію. Навіть у таких умовах необхідно мати заощадження та великий рівень доходів. Рівень середньої заробітної плати в Україні досить низький, він не здатний сприяти накопиченню коштів для здійснення значних вкладень у покупку житла. Щорічно рівень заробітної плати зростає, що доводять показники, наведені на рис. 2 [8].

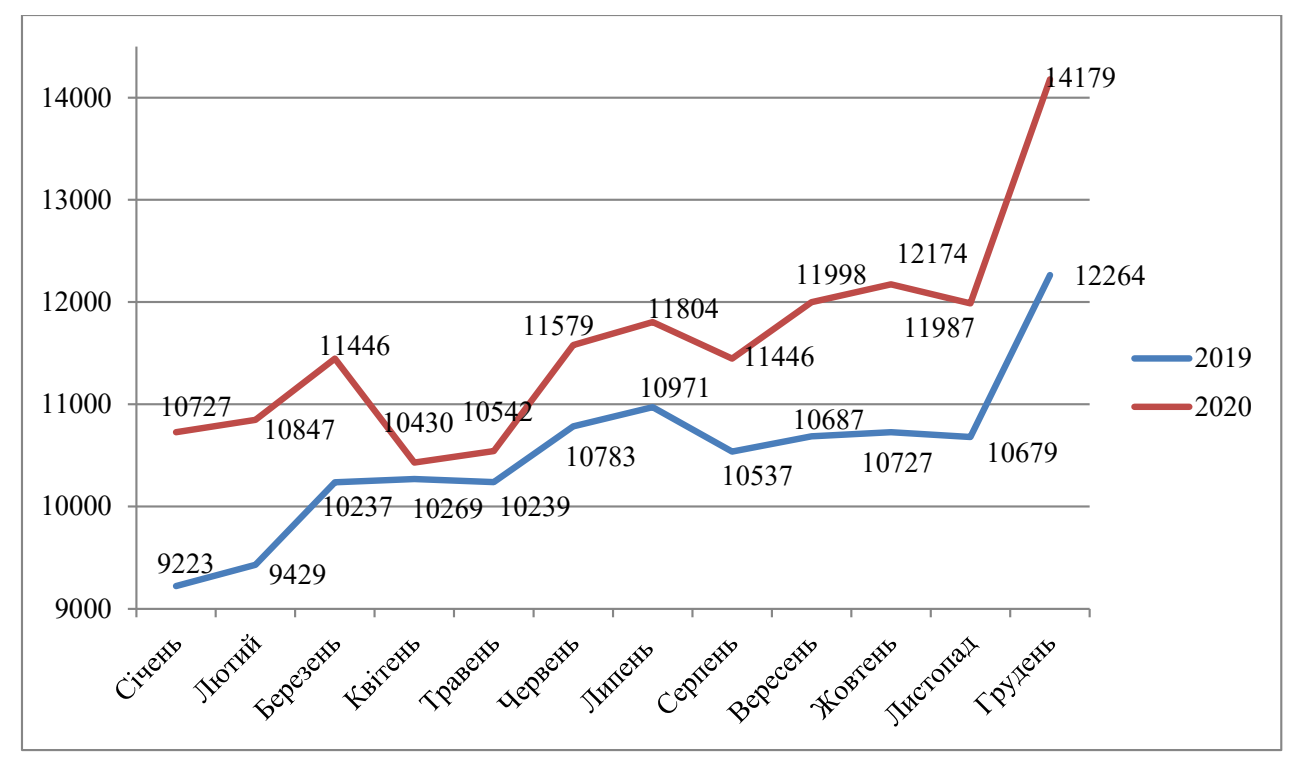

Рис. 2. Динаміка середньої заробітної плати, грн

Джерело: сформовано авторами на основі [8]

Динаміка зміни рівня середньої заробітної плати демонструє поступове збільшення, але він є недостатнім для суттєвого поліпшення добробуту населення. Незважаючи на приріст заробітних плат, зростання рівня доходності населення 3 кожним роком усе менше. Так, приріст доходів населення у 2017 р. становив 29,29\%, у 2018 р. - 21,4\%, 2019 р. - 14,9\%, у 2020 р. - 7,38\% [9]. Така тенденція пов'язана з ростом безробіття та міграцією трудових ресурсів. Таким чином, практика вкладення власних коштів у купівлю житла на стадії будівництва є дуже обмеженою та не поширюється настільки, щоб суттєво вплинути на фінансування будівництва. Отже, це доводить необхідність перегляду структури та часток різних видів житлового будівництва, що мають ураховувати у своїй діяльності будівельні організації, для підвищення використання влас- 
них ресурсів та раціонального формування вартості будівельно-монтажних робіт та цін на житло.

Висновки. Зміни, які відбувалися на ринку нерухомості, а саме у житловому будівництві, доводять необхідність постійного аналізу та контролю ситуації у зв'язку 3 динамічністю чинників впливу, які викликають відхилення фактичних результатів від запланованих, що відображається на рівні доходності будівельних організацій.

Слід приділяти більшу увагу вибраним видам житлового будівництва, оскільки орієнтація на будівництво багатоквартирних будівель не завжди є найбільш вигідним та прибутковим сегментом. Соціальні та економічні чинники в останні роки сприяють зміні рівня попиту на приватні будинки та таун-хауси. Це $є$ перспективним напрямом для невеликих будівельних організацій, оскільки таке будівництво має більш короткі терміни зведення будівель, більш зручний та доступний графік капітальних вкладень, що, враховуючі зростаючий попит, дасть організаціям змогу отримувати достатній прибуток регулярно та більш надійно.

Ще однією перевагою переорієнтації діяльності на будівництво приватних будинків можна вважати більшу фінансову доступність такого житла, оскільки у такому разі покупець має більший вибір власних бажань та рішень, які можуть відповідати дуже великому ціновому діапазону. Однак під час розрахунків слід ураховувати регіон будівництва, оскільки в різних регіонах попит на приватні будинки може значно різнитися.

\section{Список використаних джерел:}

1. Заюков I.В. Перспективи розвитку житлового будівництва України:економічний та соціальний аспект. Сучасні технологї̈, матеріали і конструкції в будівництві. 2008. № 5. С. 104-109.

2. Заяць В.С. Розвиток житлового будівництва як фактор формування житлових умов населення. Demography and Social Economy. 2019. № 2(36). C 137-151.

3. Державна служба статистики України. Загальна площа житлових будівель, прийнятих в експлуатацію за видами. Київ, 2021. URL: http://www.ukrstat.gov.ua/operativ/operativ2021/bud/ kzp/arh_kzp2021_u.htm (дата звернення: 05.05.2021).

4. Державна служба статистики України. Загальна площа житлових будівель на початок будівництва за видами. Київ, 2021. URL: http://www.ukrstat.gov.ua/operativ/operativ2020/bud/kzpb/ kzpb_u/arch_kzpb_20u.htm (дата звернення: 15.05.2021).

5. Запотоцький С., Запотоцька В., Горин І. Тенденції та перспективи житлового будівництва в Україні. Вісник Київського національного університету імені Тараса Шевченка. 2014. № 46. C. $45-49$.

6. Перетятько А.Ю. Перспективи розвитку житлового будівництва в Україні. Вісник економіки транспорту і промисловості. 2014. № 46. С. 349-353.

7. Петрищенко Н.А., Андріянов В.С., Рижова Г.Р. Дослідження ринку нерухомості в Україні. Інфраструктура ринку. 2018. № 25. С. 135-139.

8. Державна служба статистики України. Заробітна плата. Київ, 2021. URL: http://www.ukrstat.gov.ua/express/expres_u.html (дата звернення: 27.05.2021).

9. Державна служба статистики України. Доходи та витрати населення. Київ, 2021. URL: http://www.ukrstat.gov.ua/operativ/operativ2007/gdn/dvn_ric/dvn_ric_u/arh_dvn_kv_u.htm.

\section{References:}

1. Zaiukov I.V. (2008) Perspektyvy rozvytku zhytlovoho budivnytstva Ukrainy:ekonomichnyj ta sotsial'nyj aspekt [Prospects for the development of housing construction in Ukraine: economic and social aspects]. Suchasni tekhnolohii, materialy i konstruktsii v budivnytstvi, no. 5, pp. 104-109.

2. Zaiats V.S. (2019) Rozvytok zhytlovoho budivnytstva iak faktor formuvannia zhytlovykh umov naselennia [Development of housing construction as a factor in the formation of living conditions of the population]. Demography and Social Economy, no. 2 (36), pp. 137-151.

3. Derzhavna sluzhba statystyky Ukrajiny (2021) Zahalna ploscha zhytlovykh budivel, pryjniatykh $v$ ekspluatatsiiu za vydamy [The total area of residential buildings commissioned by type]. Kyiv: Informatsiino-analitychne ahentstvo (accessed 5 May 2021). 
4. Derzhavna sluzhba statystyky Ukrajiny (2021) Zahal'na ploscha zhytlovykh budivel na pochatok budivnytstva za vydamy [The total area of residential buildings at the beginning of construction by type]. Kyiv: Informatsiino-analitychne ahentstvo (accessed 15 May 2021).

5. Zapototskyj S., Zapototska V., Horyn I. (2014) Tendentsii ta perspektyvy zhytlovoho budivnytstva v Ukraini [Trends and prospects of housing construction in Ukraine]. Visnyk Kyivskoho natsionalnoho universytetu imeni Tarasa Shevchenka, no 46, pp. 45-49.

6. Peretiatko A.Yu. (2014) Perspektyvy rozvytku zhytlovoho budivnytstva v Ukraini [Prospects for housing development in Ukraine]. Visnyk ekonomiky transportu i promyslovosti, no. 46, pp. 349-353.

7. Petryschenko N.A., Andriianov V.S., Ryzhova H.R. (2018) Doslidzhennia rynku nerukhomosti v Ukraini [Real estate market research in Ukraine]. Infrastruktura rynku, no. 25, pp. 135-139.

8. Derzhavna sluzhba statystyky Ukrajiny (2021) Zarobitna plata [Salary]. Kyiv: Informatsiino-analitychne ahentstvo.

9. Derzhavna sluzhba statystyky Ukrajiny (2021) Dokhody ta vytraty naselennia [Incomes and expenditures of the population]. Kyiv: Informatsiino-analitychne ahentstvo. 